\title{
Cultures of "Clostridium acetobutylicum" from Various Collections Comprise Clostridium acetobutylicum, Clostridium beijerinckii, and Two Other Distinct Types Based on DNA-DNA Reassociation
}

\author{
J. L. JOHNSON, $†$ J. TOTH, S. SANTIWATANAKUL, $\ddagger$ AND J.-S. CHEN* \\ Department of Biochemistry and Anaerobic Microbiology, Virginia Polytechnic Institute \\ and State University, Blacksburg, Virginia 24061-0308
}

\begin{abstract}
The best-known acetone-butanol (solvent)-producing bacterium is the Weizmann organism, Clostridium acetobutylicum, which was used for starch-based industrial fermentation. In the past two decades, cultures of "C. acetobutylicum" from various culture collections have included organisms that were isolated for sugar (molasses)-based industrial solvent production. Recent biochemical and genetic studies have revealed significant differences among some of these " $C$. acetobutylicum" strains. We used DNA-DNA reassociation to analyze 39 cultures of " $C$. acetobutylicum" and phenotypically similar organisms from major collections. The results of this study clearly identified four groups with intergroup reassociation values of less than $30 \%$. All of the intragroup values except the value for one strain were $68 \%$ or more, which supported species status for each group. The $C$. acetobutylicum group (with ATCC 824 as the type strain) consisted of 17 cultures and had average reassociation values of $10 \%$ with the other three groups. All strains of $C$. acetobutylicum produced riboflavin in milk, and the cultures were bright yellow, which is useful for differentiating this species from the other three groups. The Clostridium beijerinckii group (with VPI 5481 [ = ATCC 25752] as the type strain) consisted of 16 cultures and included strains NCIMB 8052 and NCP 270. Strains NCP 262 and NRRL B643 constituted the third group, whereas strain N1-4 ("Clostridium saccharoperbutylacetonicum") and its derivative, strain N1-4081, formed the fourth group. At present, the last two groups are each represented by only one independent strain; definitive descriptions of these two groups as two new or revived species will require further phenotypic characterization, as well as identification of additional strains. $C$. beijerinckii NCP 270, Clostridium sp. strain NRRL B643, and " $C$. saccharoperbutylacetonicum" were used in industrial solvent production from molasses, which confirms that the new organisms used for the sugar-based processes are distinct from $C$. acetobutylicum.
\end{abstract}

Commercial production of acetone and butanol (solvents) by fermentation began with the Weizmann process $(15,27)$. The best-known solvent-producing bacterium is the Weizmann organism, Clostridium acetobutylicum, which was used in the corn starch-based process. After the late 1930s, molasses was used as the carbon substrate in solvent production by fermentation, and newly isolated bacteria were needed to produce solvents from sugars under practical conditions. A number of the new isolates were described as distinct Clostridium species in patents (3, 16). The taxonomy of these organisms, however, presented a difficult problem because relatively few phenotypic traits were truly useful for differentiating these organisms from $C$. acetobutylicum or from each other $(6,23,28)$. Thus, almost all historic strains of solvent-producing clostridia that are available from major culture collections have been listed as $C$. acetobutylicum.

In the past 15 years, several strains of " $C$. acetobutylicum" were subjected to detailed biochemical, physiological, and genetic analyses, and in these studies the workers detected significant differences among the strains (see reference 12 for a recent review). In several phylogenetic studies workers identified $C$. acetobutylicum (based on the 16S rRNA gene sequence of strain NCIMB 8052) as a species closely related to Clostridium beijerinckii $(5,9,18)$, which did not agree with the previous finding based on the 23S rRNA sequences (13). On the basis of

* Corresponding author. Phone: (540) 231-7129. Fax: (540) 2319070. E-mail: CHENJS@VT.EDU.

$†$ Deceased.

$\ddagger$ Present address: Department of Biology, Virginia Polytechnic Institute and State University, Blacksburg, VA 24061. an analysis of the products of pyrolysis of five strains (ATCC $824^{\mathrm{T}}$ [T = type strain], DSM 1731, NCIMB 8052, NCP 262, and N1-4081) of " $C$. acetobutylicum", as well as the 16S rRNA gene sequences of strains ATCC $824^{\mathrm{T}}$, DSM 1731, NCIMB 8052, and NCP 262, the following three groups were identified: (i) strain NCIMB 8052; (ii) strains NCP 262 and N1-4081; and (iii) strains ATCC $824^{\mathrm{T}}$ and DSM 1731 (29). Based on DNA relatedness values (12) and 16S rRNA gene sequences (29), it was proposed that " $C$. acetobutylicum" NCIMB 8052 is a $C$. beijerinckii strain $(12,29)$. By using biotyping and DNA fingerprint analysis, industrial solvent-producing clostridia were separated into nine groups $(14,16)$, and an analysis of a 550-bp region of the $16 \mathrm{~S}$ rRNA gene sequences of these organisms suggested that there were four taxonomic groups (16).

These findings point out the need to examine all available "C. acetobutylicum" cultures to determine their correct species designations. To identify strains of a species, the DNA relatedness measurement is the most discriminative technique because it involves the entire genome $(10,26)$. We used DNA-DNA reassociation to analyze 39 cultures of " $C$. acetobutylicum" and phenotypically similar organisms from major collections. Our results indicated that about one-half of the available " $C$. acetobutylicum" cultures were actually $C$. beijerinckii. In this paper, we also describe two phenotypic traits that are useful for presumptive identification of $C$. acetobutylicum.

(An outline of the major findings of this study was presented at the Third International Workshop on the Regulation of Metabolism, Genetics, and Development of the Solvent-Forming Clostridia held at Northwestern University in Evanston, Ill., on 24 and 25 June 1994.) 


\section{MATERIALS AND METHODS}

Chemicals. Special chemicals were obtained from the following sources: ${ }^{125} \mathrm{I}$ (sodium iodide), from Dupont Biotechnology Division, Wilmington, Del.; S1 nuclease, from Pharmacia Biotech, Piscataway, N.J.; proteinase K, from AMRESCO, Solon, Ohio; salmon sperm DNA (type III), lysozyme (chicken egg white), and riboflavin, from Sigma Chemical Co., St. Louis, Mo.; and Whatman GF/F glass microfiber filters, from Fisher Scientific, Pittsburgh, Pa. Pasteurized and homogenized cow's milk was purchased from a local market.

Bacterial strains. In this study we used practically all available cultures that were labeled $C$. acetobutylicum. Several other phenotypically similar solventproducing clostridia with different species designations were also included for comparison. Table 1 lists the sources of the strains used in this study. The dates of receipt are included for accuracy, and each species designation is the designation used by the culture collection or the investigator when the culture was received. Each culture was microscopically examined for uniformity in the shape and size of cells and spores. Strain NRRL B3179 was not included in this study because an authentic culture was not available.

The apparent relationships among the strains have been described by Johnson and Chen (12). The history of the strains from the McCoy collection was obtained from L. S. McClung (Indiana University) and references 17 and 20 . The following designations were used by E. McCoy and L. S. McClung for organisms that were listed in McCoy series A and B and were included in this study: Bacillus butylicus A-38, A-39, A-49, and A-50, E. McCoy butyric isolates A-8, A-13, and A-14 (from soil), C. acetobutylicum B-3, B-4, B-10, B-14, B-15, and B-16, C. beijerinckii A-67, Clostridium butylicum A-21, and Clostridium saccharoacetobutylicum A-8.

Growth. Cultures were maintained in septum-stoppered screw-cap tubes or in serum bottles fitted with septum stoppers and aluminum seals (both from Bellco, Vineland, N.J.). To facilitate the initiation of growth from spores or nongrowing cells, $\mathrm{CO}_{2}$ was added to the culture media. The media were boiled and flushed with $\mathrm{CO}_{2}$ during cooling before they were dispensed under a $\mathrm{N}_{2}$ atmosphere and sterilized. A potato infusion-salts-glucose medium (7) supplemented with $1 \mathrm{~g}$ of ammonium sulfate per liter was routinely used for preparation of inocula. Stock cultures were maintained both in the potato-based medium and in milk (1). The pasteurized and homogenized cow's milk used was either whole milk (3.8\% milk fat) or low-fat milk ( $2 \%$ milk fat), and both types of milk were satisfactory for the study of $C$. acetobutylicum.

Spores or freeze-dried cells of the strains received were revived in the potatobased medium and incubated at 35 to $37^{\circ} \mathrm{C}$. Most of the strains grew well in the potato-based medium; the only exception was strain N1-4081 (an autolysindeficient auxotroph for proline [21]), which grew faster in media containing Trypticase and yeast extract. Solvent production was tested in Trypticase-yeas extract-glucose (TYG) medium containing $20 \mathrm{~g}$ of glucose per liter as described by George et al. (7), except that the cultures were grown in $3 \mathrm{ml}$ of TYG medium in Bellco screw-cap anaerobic culture tubes. The cultures used for DNA isolation were grown in a medium containing (per liter) $10 \mathrm{~g}$ of pepticase, $5 \mathrm{~g}$ of yeast extract, $20 \mathrm{~g}$ of glucose, $1.36 \mathrm{~g}$ of $\mathrm{KH}_{2} \mathrm{PO}_{4}, 0.4 \mathrm{~g}$ of $\mathrm{MgSO}_{4}, 2 \mathrm{~g}$ of $\left(\mathrm{NH}_{4}\right)_{2} \mathrm{SO}_{4}$, $1 \mathrm{~g}$ of asparagine, $0.5 \mathrm{~g}$ of cysteine- $\mathrm{HCl}, 0.01 \mathrm{~g}$ of biotin, $0.01 \mathrm{~g}$ of $p$-aminobenzoic acid, $1 \mathrm{ml}$ of a mineral salts solution (7), and enough $\mathrm{H}_{2} \mathrm{O}$ to bring the volume to 1 liter. The $\mathrm{pH}$ was adjusted to 6.0 before sterilization. The $400-\mathrm{ml}$ cultures used for DNA isolation were grown in 1-liter Erlenmeyer flasks fitted with pressure relief valves, and each flask was flushed with a mixed gas $\left(\mathrm{CO}_{2}-\mathrm{H}_{2}-\mathrm{N}_{2}\right.$, 10:10:80) before inoculation. Each 400-ml culture was inoculated with 20 to 40 $\mathrm{ml}$ of an actively growing culture $\left(10\right.$ to $12 \mathrm{~h}$ old) and incubated at $37^{\circ} \mathrm{C}$ with shaking for 8 to $9 \mathrm{~h}$ before harvesting. The cells were used immediately for DNA isolation.

Isolation of DNA. DNA was isolated by a variation of the Marmur procedure (11). The lysing solution was heated in a boiling water bath before use, and nucleic acids were dissolved in Tris-EDTA buffer before treatment with RNases and after the final step of purification. Cells of Clostridium sp. strain NCP 262 were converted to protoplasts (31) before lysis.

Measurement of DNA reassociation. DNAs of reference strains were labeled with ${ }^{125}$ I by using the procedure of Johnson (11), with the following modifications: the buffer-salt solution contained $7.2 \mathrm{M}$ sodium perchlorate, $0.3 \mathrm{mM}$ potassium iodide, and $80 \mathrm{mM}$ sodium acetate buffer ( $\mathrm{pH} \mathrm{4.8}$ ); the $\mathrm{TlCl}_{3}$ solution contained $1 \mathrm{mg}$ of $\mathrm{TlCl}_{3}$ per $\mathrm{ml}$ in $100 \mathrm{mM}$ sodium acetate buffer $(\mathrm{pH} 4.8)$; and phosphate buffer-mercaptoethanol was omitted from the procedure. The degree of DNA reassociation was measured by the $S 1$ nuclease procedure (11), except that the buffer for the reaction mixture contained $13.2 \times$ SSC $(1 \times$ SSC is $0.15 \mathrm{M}$ $\mathrm{NaCl}$ plus $0.015 \mathrm{M}$ sodium citrate) and $5 \mathrm{mM}$ HEPES ( $N$-2-hydroxyethylpiperazine- $N^{\prime}$-2-ethanesulfonic acid) ( $\left.\mathrm{pH} 7.0\right)$, and the reaction mixture was incubated at $60^{\circ} \mathrm{C}$ for $24 \mathrm{~h}$. During the reassociation reaction, single-stranded, labeled DNA fragments from a reference strain were mixed with a large excess of singlestranded, unlabeled DNA fragments from a test strain or the reference strain. After duplex formation, single-stranded DNA was digested with S1 nuclease, and the duplexes were precipitated and collected on a fiberglass membrane filter. The radioactivity on the filter was measured and used to calculate similarity values.

Analysis of cellular fatty acids. The cellular fatty acid profiles were determined by the procedure described by Moore et al. (21). Each profile was compared with the profiles of the clostridia included in the VPI Anaerobic Bacteria Database, version 3.8 (MIDI, Newark, Del.).
TABLE 1. Sources, designations, and dates of receipt of strains of $C$. acetobutylicum and phenotypically similar organisms used in this study

\begin{tabular}{|c|c|c|}
\hline Strain & $\begin{array}{l}\text { Date of receipt } \\
\quad(\mathrm{mo} / \mathrm{yr})\end{array}$ & Source $^{a}$ \\
\hline \multicolumn{3}{|l|}{ C. acetobutylicum strains } \\
\hline ATCC $824^{\mathrm{T}}$ & $11 / 1982$ & Gherna \\
\hline ATCC 3625 & 6/1994 & Gherna \\
\hline ATCC 4259 & $11 / 1982$ & Gherna \\
\hline ATCC 8529 & $6 / 1994$ & Gherna \\
\hline ATCC 10132 & $11 / 1982$ & Gherna \\
\hline ATCC 35702 & $6 / 1994$ & Gherna \\
\hline ATCC 39057 & $6 / 1994$ & Gherna \\
\hline ATCC 39236 & $6 / 1994$ & Gherna \\
\hline ATCC 43084 & $6 / 1994$ & Gherna \\
\hline DSM 792 & $12 / 1993$ & Dürre \\
\hline DSM 1731 & $12 / 1993$ & Dürre \\
\hline DSM 1732 & $7 / 1994$ & Dürre \\
\hline NCIMB 619 & $11 / 1993$ & Pirrie \\
\hline NCIMB 2951 & $11 / 1993$ & Pirrie \\
\hline NCIMB 6441 & $11 / 1993$ & Pirrie \\
\hline NCIMB 6442 & $11 / 1993$ & Pirrie \\
\hline NCIMB 6443 & $11 / 1993$ & Pirrie \\
\hline NCIMB 6444 & $11 / 1993$ & Pirrie \\
\hline NCIMB 6445 & $11 / 1993$ & Pirrie \\
\hline NCIMB 8049 & $11 / 1993$ & Pirrie \\
\hline NCIMB $8052[57]^{b}$ & $11 / 1993$ & Pirrie \\
\hline NCIMB 8052[Y] $]^{b}$ & $12 / 1993$ & Young \\
\hline NCP 193 & $9 / 1994$ & Jones \\
\hline NCP 262 & $12 / 1993$ & Woods \\
\hline NCP 270 & 9/1994 & Jones \\
\hline NCP 271 & $9 / 1994$ & Jones \\
\hline $\mathrm{N} 1-4081$ & $11 / 1993$ & Reysset \\
\hline NRRL B527 & $2 / 1981$ & Nakamura \\
\hline NRRL B528 & $1 / 1994$ & Nakamura \\
\hline NRRL B529 & $1 / 1994$ & Nakamura \\
\hline NRRL B591 & $1 / 1994$ & Nakamura \\
\hline NRRL B594 & $1 / 1994$ & Nakamura \\
\hline NRRL B643 & $1 / 1994$ & Nakamura \\
\hline C. beijerinckii VPI $5481^{\mathrm{T}}$ & $7 / 1981$ & VPI \\
\hline \multicolumn{3}{|l|}{ C. butylicum strains } \\
\hline NRRL B466 & $1 / 1994$ & Nakamura \\
\hline NRRL B592 ${ }^{c}$ & $2 / 1981$ & Nakamura \\
\hline NRRL B593 ${ }^{c}$ & $2 / 1981$ & Nakamura \\
\hline NRRL B596 & $1 / 1994$ & Nakamura \\
\hline "C. saccharoperbutylacetonicum" N1-4 & $1 / 1994$ & Yoshino \\
\hline
\end{tabular}

${ }^{a}$ Gherna, R. Gherna, American Type Culture Collection; Dürre, P. Dürre, University of Göttingen; Pirrie, R. S. Pirrie, National Collection of Industrial and Marine Bacteria; Young, M. Young, University of Wales; Jones, D. T. Jones, University of Otago; Woods, D. R. Woods, University of Cape Town; Reysset, G. Reysset, Pasteur Institute; Nakamura, L. K. Nakamura, U.S. Department of Agriculture; VPI, VPI Anaerobe Laboratory Culture Collection; Yoshino, S. Yoshino, Kyushu University.

b. NCIMB 8052[57] is a direct subculture from a May 1957 culture of NCIMB 8052. NCIMB 8052[Y] is a current laboratory culture of $M$. Young.

${ }^{c}$ NRRL B592 and NRRL B593 have been identified as C. beijerinckii (7).

Analytical procedures. The concentrations of acetone, butanol, and isopropanol in culture supernatants were measured by gas chromatography as described previously (30)

\section{RESULTS}

Differentiation of solvent-producing clostridia. Eleven cultures were chosen as the reference strains for this study. These cultures included the type strains of $C$. acetobutylicum and $C$. beijerinckii. The other reference strains represented apparently 
TABLE 2. Levels of DNA sequence similarity for $C$. acetobutylicum-like bacteria

\begin{tabular}{|c|c|c|c|c|c|c|c|c|c|c|c|c|}
\hline \multirow[b]{2}{*}{ Species } & \multirow[b]{2}{*}{ Strain } & \multicolumn{11}{|c|}{$\%$ Similarity with: } \\
\hline & & $\begin{array}{l}\text { ATCC } \\
824^{T}\end{array}$ & $\begin{array}{l}\text { DSM } \\
1731\end{array}$ & $\begin{array}{c}\text { VPI } \\
5481^{\mathrm{T}}\end{array}$ & $\begin{array}{c}\text { NCIMB } \\
8052[57]^{a}\end{array}$ & $\begin{array}{l}\text { NCIMB } \\
8052[Y]^{a}\end{array}$ & $\begin{array}{c}\text { NRRL } \\
\text { B594 }\end{array}$ & $\begin{array}{c}\text { NRRL } \\
\text { B592 }\end{array}$ & $\begin{array}{c}\text { NCP } \\
270\end{array}$ & $\begin{array}{c}\text { NCIMB } \\
6444\end{array}$ & $\begin{array}{c}\text { NRRL } \\
\text { B643 }\end{array}$ & N1-4 \\
\hline \multirow[t]{17}{*}{ C. acetobutylicum } & ATCC $824^{\mathrm{T}}$ & $(100)$ & 98 & 7 & 13 & 20 & 6 & $\mathrm{ND}^{b}$ & ND & ND & 7 & 12 \\
\hline & ATCC 3625 & 98 & 102 & 15 & 13 & 14 & 16 & ND & ND & ND & 6 & 7 \\
\hline & ATCC 4259 & 99 & 98 & 12 & 11 & 10 & 6 & ND & ND & ND & 8 & 7 \\
\hline & ATCC 8529 & 92 & 104 & 5 & 10 & 4 & 5 & ND & ND & ND & 4 & 5 \\
\hline & ATCC 39236 & 101 & 102 & 17 & 25 & 22 & 21 & ND & ND & ND & 9 & 11 \\
\hline & ATCC 43084 & 105 & 110 & 16 & 20 & 19 & 18 & ND & ND & ND & 8 & 11 \\
\hline & DSM 792 & 92 & 96 & 9 & 8 & 8 & 6 & ND & ND & ND & 9 & 13 \\
\hline & DSM 1731 & 96 & $(100)$ & 7 & 12 & 10 & 7 & ND & ND & ND & 8 & 6 \\
\hline & DSM 1732 & 96 & 99 & 17 & 17 & 20 & 24 & ND & ND & ND & 9 & 9 \\
\hline & NCIMB 619 & 96 & 104 & 5 & 4 & 6 & 5 & ND & ND & ND & 5 & 5 \\
\hline & NCIMB 2951 & 97 & 94 & 8 & 12 & 15 & 7 & ND & ND & ND & 8 & 9 \\
\hline & NCIMB 6441 & 93 & 99 & 5 & 5 & 5 & 5 & ND & ND & ND & 5 & 7 \\
\hline & NCIMB 6442 & 97 & 98 & 6 & 4 & 7 & 5 & ND & ND & ND & 6 & 14 \\
\hline & NCIMB 6443 & 97 & 97 & 6 & 7 & 6 & 4 & ND & ND & ND & 5 & 5 \\
\hline & NRRL B527 & 95 & 96 & 6 & 6 & 11 & 5 & ND & ND & ND & 7 & 5 \\
\hline & NRRL B528 & 84 & 87 & 9 & 10 & 10 & 9 & ND & ND & ND & 7 & 5 \\
\hline & NRRL B529 & 94 & 101 & 10 & 15 & 13 & 10 & ND & ND & ND & 7 & 8 \\
\hline \multirow[t]{18}{*}{ C. beijerinckii } & VPI $5481^{\mathrm{T}}$ & 4 & 10 & $(100)$ & 83 & 73 & 84 & 76 & 74 & 57 & 22 & 18 \\
\hline & ATCC 10132 & 10 & 10 & 76 & 97 & 93 & 99 & 71 & 76 & 66 & 20 & 19 \\
\hline & ATCC 35702 & 7 & 5 & 72 & 103 & 95 & 97 & 74 & 73 & 54 & 18 & 17 \\
\hline & ATCC 39057 & 6 & 5 & 81 & ND & ND & ND & ND & ND & ND & 20 & 21 \\
\hline & NCIMB 6444 & 24 & 32 & 73 & 78 & 79 & 77 & 68 & 68 & $(100)$ & 21 & 23 \\
\hline & NCIMB 6445 & 9 & 10 & 84 & 108 & 98 & 101 & 80 & 80 & 79 & 21 & 12 \\
\hline & NCIMB 8049 & 6 & 10 & 82 & 108 & 98 & 98 & 77 & 83 & 80 & 21 & 21 \\
\hline & NCIMB 8052[57] & 4 & 8 & 78 & $(100)$ & 101 & 98 & 79 & 81 & 65 & 20 & 20 \\
\hline & NCIMB 8052[Y] & 7 & 8 & 78 & 97 & $(100)$ & 98 & 79 & 81 & 61 & 22 & 24 \\
\hline & NCP 193 & 8 & 11 & 82 & 80 & 82 & 84 & 73 & 100 & 65 & 22 & 18 \\
\hline & NCP 270 & 5 & 4 & 82 & 89 & 83 & 79 & 72 & $(100)$ & 75 & 18 & 20 \\
\hline & NCP 271 & 18 & 17 & 81 & 83 & 87 & 84 & 75 & 103 & 72 & 20 & 21 \\
\hline & NRRL B466 & 7 & 9 & 79 & 85 & 86 & 86 & 94 & 80 & 76 & 24 & 23 \\
\hline & NRRL B591 & 12 & 22 & 84 & 105 & 99 & 101 & 75 & 78 & 72 & 20 & 19 \\
\hline & NRRL B592 & 3 & 5 & 76 & 89 & 79 & 81 & (100) & 73 & 77 & 18 & 19 \\
\hline & NRRL B593 & 5 & 4 & 75 & 80 & 77 & 75 & 73 & 75 & 80 & 22 & 19 \\
\hline & NRRL B594 & 6 & 8 & 83 & 108 & 102 & $(100)$ & 79 & 75 & 67 & 20 & 20 \\
\hline & NRRL B596 & 18 & 19 & 77 & 89 & 85 & 90 & 98 & 80 & 67 & 22 & 21 \\
\hline \multirow{4}{*}{ Others } & NCP 262 & 14 & 26 & 21 & 25 & 22 & 21 & ND & ND & ND & 94 & 19 \\
\hline & NRRL B643 & 5 & 12 & 20 & 24 & 19 & 19 & ND & $\mathrm{ND}$ & ND & (100) & 15 \\
\hline & N1-4 & 23 & 25 & 24 & 23 & 23 & 24 & ND & ND & ND & 21 & (100) \\
\hline & N1-4081 & 4 & 8 & 26 & 31 & 24 & 26 & ND & ND & ND & 20 & 99 \\
\hline
\end{tabular}

${ }^{a}$ NCIMB 8052[57] is a direct subculture from a May 1957 culture of NCIMB 8052. NCIMB 8052[Y] is a current laboratory culture of M. Young. ${ }^{b} \mathrm{ND}$, not determined.

distinct lineages described by Johnson and Chen (12). The results of DNA reassociation measurements (Table 2) clearly separated the 39 cultures into four groups (Fig. 1). Within each group, the level of DNA sequence similarity was generally $70 \%$ or higher, whereas between groups the degree of DNA sequence similarity never exceeded $32 \%$. The results indicated that the cultures belonged to four species (10).

The first group, which contained 17 cultures, was represented by strain ATCC 824 , the type strain of $C$. acetobutylicum, and hence comprised this species. This species assignment was supported by the presence in this group of strains DSM 792 and NRRL B527, which are considered equivalent to strain ATCC $824^{\mathrm{T}}$. Cultures NCIMB 8052[57] and NCIMB 8052[Y], which exhibited less than $8 \%$ DNA sequence similarity to strain ATCC $824^{\mathrm{T}}$, were obviously not $C$. acetobutylicum strains. Within this group, only strain NRRL B528 exhibited levels of DNA sequence similarity ( 84 to $87 \%$ ) that were significantly lower than those of the other strains in comparison with the reference strains. Thus, authentic strains of $C$. acetobutylicum are genetically very similar.
The second group, which contained 18 cultures, was represented by strain VPI 5481, the type strain of $C$. beijerinckii, and hence comprised this species. Most of the cultures in this group, including NCIMB 8052, have been labeled C. acetobu-

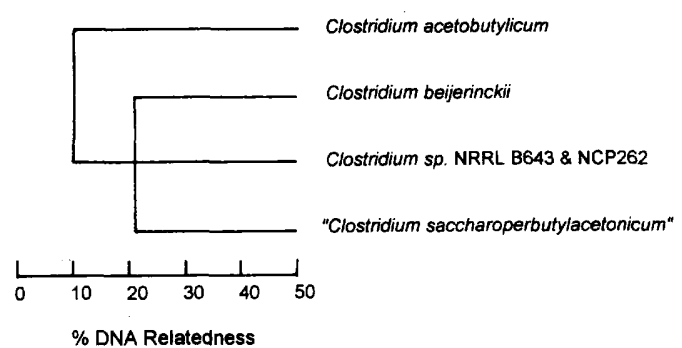

FIG. 1. Dendrogram showing levels of DNA relatedness among $C$. acetobutylicum, C. beijerinckii, Clostridium sp. strains NRRL B643 and NCP 262, and " $C$ saccharoperbutylacetonicum." The average percentages of similarity from Table 2 were clustered by using the unweighted pair group method. 
tylicum previously. Among the strains of $C$. beijerinckii, there was a broad range of levels of DNA sequence similarity, and strain NCIMB 6444 exhibited relatively low levels of similarity (as low as 54\%) to some strains of $C$. beijerinckii. Therefore, the strains of $C$. beijerinckii are genetically more diverse than the strains of $C$. acetobutylicum.

The third group consisted of Clostridium sp. strains NCP 262 (2) and NRRL B643. These two cultures were highly related to each other and belonged to the same species. A search of the cellular fatty acid profiles in the VPI Anaerobic Bacteria Database did not reveal a match between strain NRRL B643 and any presently recognized Clostridium species. It has been reported (14) that strain NRRL B643 represents "Clostridium saccharo-butyl-acetonicum-liquefaciens," an organism used in industrial solvent production from molasses after 1938. Strain NCP 262 was perhaps derived from strain NRRL B643, or both were derived from a common parent strain (16).

The fourth group consisted of Clostridium sp. strain N1-4 (8) and its derivative, strain N1-4081 (22). The parent organism was named "Clostridium saccharoperbutylacetonicum" (8), but its derivatives have been referred to as $C$. acetobutylicum (22). The DNA reassociation data established that this group is a separate species. "C. saccharoperbutylacetonicum" was not included on the Approved Lists of Bacterial Names (24).

Useful phenotypic traits for identification of $C$. acetobutylicum. DNA relatedness, as illustrated in Fig. 1, provides an unambiguous criterion for separation of bacterial species $(10$, 26). However, measuring levels of DNA reassociation is not practical in many laboratories, and phenotypic traits that correlate with the species established by DNA relatedness remain valuable for proper identification of species. During this study, the two phenotypic traits described below were found to be useful for presumptive identification of C. acetobutylicum.

(i) Production of riboflavin in milk medium. Milk is an excellent medium for maintenance of all of the strains used in this study. The stock cultures were incubated at $37^{\circ} \mathrm{C}$ for 5 days and then stored at $4^{\circ} \mathrm{C}(1)$. The rate of curd formation was the first useful criterion for differentiation of species. " $C$. saccharoperbutylacetonicum" did not cause curd formation during the first $48 \mathrm{~h}$, whereas the other three species caused curd formation within $24 \mathrm{~h}$, with the strains of $C$. acetobutylicum giving the fastest reaction. After storage at $4^{\circ} \mathrm{C}$ for about 10 days, a bright yellow color started to appear in milk cultures of all strains of C. acetobutylicum but not in any culture of the other three species (data not shown; color photographs of the cultures are available upon request). The color intensity increased with time during the first several weeks and became stable thereafter. This color formation was easier to observe in tube cultures than in bottle cultures because the zone of clear whey was more conspicuous in the tubes. Visible absorption spectra of yellow culture filtrates had an absorption peak at $445 \mathrm{~nm}$ (data not shown), which is consistent with the spectrum of riboflavin. Production of riboflavin by C. acetobutylicum in low-metal media was once a useful industrial process (27). Based on an $\varepsilon$ of $11 \mathrm{mM}^{-1} \mathrm{~cm}^{-1}$ at $445 \mathrm{~nm}$ and $\mathrm{pH} 4.5$, the culture filtrates of C. acetobutylicum strains contained maximal riboflavin concentrations of 5 to $15 \mu \mathrm{M}$. Apparently, milk provides the right conditions for production of riboflavin by $C$. acetobutylicum, and the concomitant appearance of a bright yellow color is the most distinctive phenotypic trait of $C$. acetobutylicum.

(ii) Production of $\boldsymbol{n}$-butanol in TYG medium. We previously reported poor solvent production by $C$. acetobutylicum in TYG medium containing $20 \mathrm{~g}$ of glucose per liter (7). The average concentration of $n$-butanol produced by the 17 cultures of $C$. acetobutylicum in TYG medium was $9.0 \mathrm{mM}$ (range, 3.9 to 25 $\mathrm{mM})$. The average concentration of $n$-butanol produced by the
18 cultures of $C$. beijerinckii in the same medium was $48 \mathrm{mM}$ (range, 0.9 to $86 \mathrm{mM}$ ). It is interesting that $C$ : beijerinckii NCP 270 , which is one of the most recently used industrial strains (25), and C. beijerinckii NCP 271 produced the highest levels of butanol ( 75 and $86 \mathrm{mM}$, respectively) in this sugar-based medium. Strains NCP 262 and NRRL B643 produced 49 and 28 $\mathrm{mM} n$-butanol, respectively, whereas strain N1-4 produced 28 $\mathrm{mM}$. Thus, if a culture produces more than $30 \mathrm{mM}$ butanol in TYG medium, it is reasonably certain that the culture is not a $C$. acetobutylicum culture; however, the reverse is not true because solvent-producing clostridia degenerate easily $(4,7$, 12). This property is useful for detection of a culture that has been mislabeled or misidentified as $C$. acetobutylicum.

\section{DISCUSSION}

Based on DNA relatedness values (this study) and $16 \mathrm{~S}$ rRNA gene sequences (16), the historical strains, as well as some more recent isolates of solvent-producing clostridia, clearly belong to four species; C. acetobutylicum ATCC $824^{\mathrm{T}}$, C. beijerinckii VPI $5481^{\mathrm{T}}$ (= ATCC $25752^{\mathrm{T}}$ ), Clostridium sp. strain NRRL B643 (or NCP 262), and " $C$. saccharoperbutylacetonicum" N1-4 represent these four groups. The last two groups are each represented by one independent strain, and the historical backgrounds of these two strains have been described by Keis et al. (16). At present, there is insufficient phenotypic information to allow definitive descriptions of the two species encompassing these two strains, although Clostridium sp. strain NRRL B643 can be differentiated from the other three groups by phenotypic traits (see below). Further phenotypic characterization of the last two groups of organisms is in progress in the laboratories from which we obtained these strains. Descriptions of these two groups of organisms as two species should not be published until more phenotypic traits, and preferably more strains, are available.

Identification and classification of solvent-producing clostridia have been difficult because these organisms have few phenotypic differences. The solvent-producing clostridia were once classified as the butyl organisms to distinguish them from the true butyric anaerobes $(19,20)$. In the late $1920 \mathrm{~s}$, the species $C$. acetobutylicum was proposed to include strains that produced solvents from starch $(19,28)$. This use of solvent production as a primary criterion for taxonomy was a source of serious problems because solvent production is an unstable trait whose manifestation changes dramatically when growth conditions change or when strains degenerate $(4,7,12)$. The metabolic switch between the acid- and solvent-producing phases, which is accompanied by changes in the culture $\mathrm{pH}$, the profiles of fermentation products, and the profiles of cellular fatty acids, makes the task even more difficult.

When molecular approaches are used, the four species of solvent-producing clostridia can be reliably differentiated. In addition to measurements of DNA relatedness (Fig. 1), the complete sequences of the 16S rRNA genes of representatives of the four groups are available from GenBank under the following accession numbers: $C$. acetobutylicum ATCC $824^{\mathrm{T}}$, $\mathrm{U} 16166$ and X78070; C. beijerinckii DSM $791\left(=\mathrm{ATCC} 25752^{\mathrm{T}}\right)$ X68179; C. beijerinckii NCIMB 9362 (= ATCC $\left.25752^{\mathrm{T}}\right)$, X68180; Clostridium sp. strain NCP 262, U16147 and X78073; and "C. saccharoperbutylacetonicum" N1-4, U16122. The 550-nucleotide region between positions 830 and 1383 (Escherichia coli numbering) is useful for differentiating these four species (16). Pyrolysis mass spectrometry has been used to separate six strains of solvent-producing clostridia into four groups corresponding to the four species, except that strains NCP 262 and N1-4081 (a deriv- 
ative of strain N1-4) were not separated as clearly as the other taxa (29).

C. acetobutylicum and $C$. beijerinckii have been differentiated by the requirement of $C$. acetobutylicum for a fermentable carbohydrate for growth, and a definitive test may be based on the results of this study and the results of Keis et al. (16). The following phenotypic traits should be useful for differentiating the solvent-producing clostridia: $C$. acetobutylicum is susceptible to 10 and $100 \mathrm{ng}$ of rifampin per disc (16) and produces riboflavin to give a bright yellow color in milk; the Clostridium sp. represented by strains NRRL B643 and NCP 262 is susceptible to 10 and $100 \mathrm{ng}$ of rifampin per disc (16) but does not produce riboflavin in milk; and $C$. beijerinckii and " $C$. saccharoperbutylacetonicum" are resistant to 10 and $100 \mathrm{ng}$ of rifampin per disc (16) and do not produce riboflavin in milk. A reliable phenotypic trait for differentiating $C$. beijerinckii and "C. saccharoperbutylacetonicum" has not been determined yet Nevertheless, all laboratory strains of solvent-producing $C$. beijerinckii have been correctly identified by DNA relatedness data.

\section{ACKNOWLEDGMENTS}

We are grateful to the investigators listed in Table 1 for providing cultures, to the late W. E. C. Moore for analyzing the cellular fatty acid profile of strain NRRL B643, and to A. Ismaiel for analyzing the visible absorption spectra of the culture supernatants. We are saddened by the deaths of John L. Johnson and W. E. C. Moore shortly after the completion of this study.

This study was supported by U.S. Department of Energy grant DE-FG05-85-ER13368 and by the Cooperative State Research Service, U.S. Department of Agriculture, under project 6129960.

\section{REFERENCES}

1. Bahl, H., W. Andersch, and G. Gottschalk. 1982. Continuous production of acetone and butanol by Clostridium acetobutylicum in a two-stage phosphate limited chemostat. Appl. Microbiol. Biotechnol. 15:201-205.

2. Barber, J. M., F. T. Robb, J. R. Webster, and D. R. Woods. 1979. Bacteriocin production by Clostridium acetobutylicum in an industrial fermentation process. Appl. Environ. Microbiol. 37:433-437.

3. Beesch, S. C. 1952. Acetone-butanol fermentation of sugars. Ind. Eng. Chem. 44:1677-1682.

4. Chen, J.-S., and S. F. Hiu. 1986. Acetone-butanol-isopropanol production by Clostridium beijerinckii (synonym, Clostridium butylicum). Biotechnol. Lett. 8:371-376.

5. Collins, M. D., P. A. Lawson, A. Willems, J. J. Cordoba, J. FernandezGarayzabal, P. Garcia, J. Cai, H. Hippe, and J. A. E. Farrow. 1994. The phylogeny of the genus Clostridium: proposal of five new genera and eleven new species combinations. Int. J. Syst. Bacteriol. 44:812-826.

6. Cummins, C. S., and J. L. Johnson. 1971. Taxonomy of the clostridia: wall composition and DNA homologies in Clostridium butyricum and other butyric acid-producing clostridia. J. Gen. Microbiol. 67:33-46.

7. George, H. A., J. L. Johnson, W. E. C. Moore, L. V. Holdeman, and J.-S. Chen. 1983. Acetone, isopropanol, and butanol production by Clostridium beijerinckii (syn. Clostridium butylicum) and Clostridium aurantibutyricum. Appl. Environ. Microbiol. 45:1160-1163.

8. Hongo, M., and A. Murata. 1965. Bacteriophages of Clostridium saccharo perbutylacetonicum. I. Some characteristics of the twelve phages obtained from the abnormally fermented broths. Agric. Biol. Chem. 29:1135-1139.

9. Hutson, R. A., D. E. Thompson, and M. D. Collins. 1993. Genetic interre- lationships of saccharolytic Clostridium botulinum types B, E and F and related clostridia as revealed by small-subunit rRNA gene sequences. FEMS Microbiol. Lett. 108:103-110.

10. Johnson, J. L. 1984. Bacterial classification. III. Nucleic acids in bacteria classification, p. 8-11. In N. R. Krieg and J. G. Holt (ed.), Bergey's manual of systematic bacteriology, vol. 1. Williams and Wilkins, Baltimore, Md.

11. Johnson, J. L. 1994. Similarity analysis of DNAs, p. 655-682. In P. Gerhardt R. G. E. Murray, W. A. Wood, and N. R. Krieg (ed.), Methods for general and molecular bacteriology. American Society for Microbiology, Washington, D.C.

12. Johnson, J. L., and J.-S. Chen. 1995. Taxonomic relationships among strains of Clostridium acetobutylicum and other phenotypically similar organisms. FEMS Microbiol. Rev. 17:233-240.

13. Johnson, J. L., and B. S. Francis. 1975. Taxonomy of the clostridia: ribosomal ribonucleic acid homologies among the species. J. Gen. Microbiol. 88:229-244.

14. Jones, D. T., and S. Keis. 1995. Origins and relationships of industrial solvent-producing clostridial strains. FEMS Microbiol. Rev. 17:223-232.

15. Jones, D. T., and D. R. Woods. 1986. Acetone-butanol fermentation revisited. Microbiol. Rev. 50:484-524.

16. Keis, S., C. F. Bennett, V. K. Ward, and D. T. Jones. 1995. Taxonomy and phylogeny of industrial solvent-producing clostridia. Int. J. Syst. Bacteriol. 45:693-705.

17. Langlykke, A. F., W. H. Peterson, and E. McCoy. 1935. Products from the fermentation of glucose and arabinose by butyric acid anaerobes. J. Bacteriol. 29:333-347.

18. Lawson, P. A., P. Llop-Perez, R. A. Hutsun, H. Hippe, and M. D. Collins. 1993. Towards a phylogeny of the clostridia based on 16S rRNA sequences. FEMS Microbiol. Lett. 113:87-92.

19. McCoy, E., E. B. Fred, W. H. Peterson, and E. G. Hastings. 1926. A cultura study of the acetone butyl alcohol organism. J. Infect. Dis. 39:457-483.

20. McCoy, E., E. B. Fred, W. H. Peterson, and E. G. Hastings. 1930. A cultura study of certain anaerobic butyric-acid-forming bacteria. J. Infect. Dis. 46: 118-137.

21. Moore, L. V. H., D. M. Bourne, and W. E. C. Moore. 1994. Comparative distribution and taxonomic value of cellular fatty acids in thirty-three genera of anaerobic gram-negative bacilli. Int. J. Syst. Bacteriol. 44:338-347.

22. Reysset, G., J. Hubert, L. Podvin, and M. Sebald. 1987. Protoplast formation and regeneration of Clostridium acetobutylicum strain N1-4080. J. Gen. Microbiol. 133:2595-2600.

23. Richard, O. 1948. Variation in morphological and biochemical characteristics of anaerobic butyric acid bacteria. Nature (London) 162:463-465.

24. Skerman, V. B. D., V. McGowan, and P. H. A. Sneath. 1989. Approved lists of bacterial names, amended edition. American Society for Microbiology, Washington, D.C

25. Spivey, M. J. 1978. The acetone/butanol/ethanol fermentation. Process Biochem. 13:2-5

26. Stackebrandt, E., and B. M. Goebel. 1994. Taxonomic note: a place for DNA-DNA reassociation and 16S rRNA sequence analysis in the present species definition in bacteriology. Int. J. Syst. Bacteriol. 44:846-849.

27. Walton, M. T., and J. L. Martin. 1979. Production of butanol-acetone by fermentation, p. 187-209. In H. J. Peppler and D. Perlman (ed.), Microbial technology, 2nd ed., vol. 1. Academic Press, New York, N.Y

28. Weyer, E. R., and L. F. Rettger. 1927. A comparative study of six different strains of the organism commonly concerned in large-scale production of butyl alcohol and acetone by the biological process. J. Bacteriol. 14:399-424.

29. Wilkinson, S. R, M. Young, R. Goodacre, J. G. Morris, J. A. E. Farrow, and M. D. Collins. 1995. Phenotypic and genotypic differences between certain strains of Clostridium acetobutylicum. FEMS Microbiol. Lett. 125:199-204.

30. Yan, R.-T., C.-X. Zhu, C. Golemboski, and J.-S. Chen. 1988. Expression of solvent-forming enzymes and onset of solvent production in batch cultures of Clostridium beijerinckii ("Clostridium butylicum"). Appl. Environ. Microbiol. 54:642-648.

31. Zappe, H., D. T. Jones, and D. R. Woods. 1986. Cloning and expression of Clostridium acetobutylicum endoglucanase, cellobiase and amino acid biosynthesis genes in Escherichia coli. J. Gen. Microbiol. 132:1367-1372. 